Situs Jurnal : $\underline{\text { http://ejurnal.stiepancasetia.ac.id/index.php/jieb }}$

Jilid 5 Nomor 1 Maret 2019

Hal $052-059$

\title{
ANALISIS PENGARUH FAKTOR-FAKTOR PENYEBAB FRAUD DI SEKTOR PEMERINTAHAN KOTA BANJARBARU
}

\author{
Suzi Suzana*
}

Abstract: Government agencies as budget users, implementers of popular programs and activities, are indicated to be real perpetrators of fraud. Some conditions in the work environment that can be a stimulant for fraud such as weak, inadequate and ineffective internal control systems and inconsistencies in carrying out procedures that have been made, clearly will play a very large role in creating opportunities for fraud. This study aims to prove the influence of Pressure, Opportunity, and Rationalization on Fraud (fraud) on the Municipal Government of Banjarbaru. The results of the study of the pressure variable indicate that the Banjarbaru City Government has a significant and positive effect on fraud. This shows that the higher the pressure that exists on the employee, the higher the action will be towards fraud. The opportunity variable shows that the Banjarbaru City Government has a significant effect on fraud. This shows that the higher the opportunity there is, the lower the action against fraud. Rationalization variables indicate that the Banjarbaru City Government has a significant and positive influence on fraud. This shows that the higher the existing rationalization of employees will increase the action against fraud.

Keywords: fraud, pressure, opportunity, rationalization

Abstrak: Instansi pemerintah sebagai pengguna anggaran, pelaksana program dan kegiatan kerakyatan, terindikasi secara nyata adalah pelaku fraud. Beberapa kondisi di lingkungan kerja yang dapat menjadi stimulan bagi terjadinya fraud seperti sistem pengendalian intern yang lemah, tidak memadai dan tidak efektif serta adanya inkonsistensi dalam menjalankan prosedur yang telah dibuat, jelas akan sangat besar peranannya dalam menciptakan peluang terjadinya fraud. Penelitian ini bertujuan untuk membuktikan pengaruh Tekanan, Peluang, dan Rasionalisasi terhadap Kecurangan (fraud) pada Pemerintah Kota Banjarbaru. Hasil penelitian dari variabel tekanan menunjukkan bahwa Pemerintah Kota Banjarbaru berpengaruh secara signifikansi dan positif terhadap Kecurangan (fraud). Hal ini menunjukkan semakin tinggi tekanan yang ada terhadap pegawai maka akan meningkatkan tindakan terhadap Kecurangan (fraud). Dari variabel peluang menunjukkan bahwa Pemerintah Kota Banjarbaru berpengaruh secara signifikansi terhadap Kecurangan (fraud). Hal ini menunjukkan semakin tinggi peluang yang ada maka akan menurunkan tindakan terhadap Kecurangan (fraud). Variabel rasionalisasi menunjukkan bahwa Pemerintah Kota Banjarbaru terdapat pengaruh secara signifikansi dan positif terhadap Kecurangan (fraud). Hal ini menunjukkan semakin tinggi rasionalisasi yang ada terhadap pegawai maka akan meningkatkan tindakan terhadap Kecurangan (fraud).

Kata kunci : kecurangan, tekanan, peluang, rasionalisasi

\section{Latar Belakang}

Tindakan korupsi pada pemerintahan yang menjadi bagian dari fraud dalam akuntansi, merupakan tindakan yang menyebabkan kesalahan pelaporan dalam laporan keuangan, atau 
suatu tindakan kesengajaan untuk menggunakan sumber daya keuangan demi memberi keuntungan pribadi dan kelompok.Fraud merupakan konsep pelanggaran yang memiliki sudut pandang yang luas.Association of Certified Fraud Examiners (ACFE) menyebutkan fraud sebagai perbuatan-perbuatan melawan hukum yang dilakukan dengan sengaja untuk tujuan tertentu (manipulasi atau memberikan laporan keliru terhadap pihak lain) yang dilakukan oleh orang-orang dari dalam atau luar organisasi untuk mendapatkan keuntungan pribadi ataupun kelompok yang secara langsung atau tidak langsung merugikan pihak lain. Hall (2007) mendefinisikan fraud sebagai kebohongan yang disengaja, ketidakbenaran dalam melaporkan aset lembaga. Korupsi (corruption) terbagi ke dalam pertentangan kepentingan (conflict of interest), suap (bribery), pemberian illegal (illegal gratuity), dan pemerasan (economic extortion). Pengertian korupsi ini tentu saja berbeda dengan pengertian korupsi yang terkandung dalam Undang-undang 31 tahun 1999 jo Undang-undang 20 tahun 2001. Dalam bahasa hukum positif (UU No. 31 Tahun 1999 jo UU 20 Tahun 2001 tentang Pemberantasan Tindak Pidana Korupsi) pengertian korupsi secara umum, adalah perbuatan yang diancam dengan ketentuan pasal-pasal UU No 31 tahun 1999. Dalam salah satu pasal, korupsi terjadi apabila memenuhi tiga kriteria yang merupakan syarat bahwa seseorang bisa dijerat dengan undang-undang korupsi, ketiga syarat tersebut adalah melawan hukum, memperkaya diri sendiri atau orang lain atau korporasi, dan merugikan keuangan negara atau perkonomian negara. Dengan kriteria tersebut maka orang yang dapat dijerat dengan undang-undang korupsi, bukan hanya pejabat negara saja melainkan pihak swasta yang ikut terlibat dan badan usaha/korporasi pun dapat dijerat dengan ketentuan undang-undang korupsi. Melihat trend yang ada mulai dari mahar politik ataupun fee proyek sudah saatnya kepala daerah menata kembali sistem dan mental mereka. Indonesia Corruption Watch (ICW) mencatat sepanjang tahun 2017 ada sebanyak 241 kasus korupsi dan suap terkait pengadaan sektor infrastruktur akibatnya negara merugi Rp.1,5 triliun dengan nilai suap mencapai Rp.34 miliar. Kerugian negera di tahun 2016 akibat korupsi pengadaan infrastruktur sebesar Rp. 680 miliar

Kalimantan Selatan sebetulnya kondusif tapi faktanya justru banyak terjadi tindak pidana korupsi, menjadi pertanyaan apakah korupsi itu menjadi kebiasaan ? jangan sampai korupsi menjadi kebiasaan dan dibenarkan dilingkungan pemerintahan, maka pola-pola seperti ini yang harus dirubah

Dalam kasus tipikor para pelaku sepertinya selalu selangkah lebih maju dibanding dengan sistem pengendalian eksternal yang telah dirancang sedemikian rupa untuk mencegah adanya fraud, sistem pengendalian internal dalam organisasi itu sendiri pun belum tentu mampu untuk mencegah adanya fraud. Apalagi jika para pelaku adalah orang-orang yang melaksanakanpengendalian dan juga merupakan orang-orang yang memiliki kuasa di dalam organisasi tersebutmemudahkan mereka melakukan aksi fraud dengan leluasa. Beberapa kondisi di lingkungan kerja yang dapat menjadi stimulan bagi terjadinya fraud seperti sistem pengendalian intern yang lemah, sistem pengendalian yang tidak memadai dan tidak efektif serta adanya inkonsistensi dalam menjalankan prosedur yang telah dibuat, jelas akan sangat besar peranannya dalam menciptakan peluang terjadinya fraud. Berbagai referensi memberikan terminologi mengenai fraud, namun pada intinya diperoleh konsep dasar mengenai arti fraud yang diartikan sebagai pelanggaran dan penyimpangan yang dilakukan dengan menimbulkan kerugian bagi pemerintah baik secara langsung atau tidak langsung dan memberikan keuntungan bagi pelakunya.fraud yang terjadi dapat mempengaruhi secara negatif dalam banyak hal baik dalam keuangan, reputasi, psikologi dan implikasi sosial. Para pelakunya dapat dari level terendah sampai dengan level tertinggi. Mengenai pentingnya pencegahan tindakan fraud baik itu terjadi maupun yang akan terjadi mengharuskan pihak manajemen untuk mengerti mengenai fraud itu sendiri serta tindakan yang tegas dalam mencegah fraud itu terjadi. 
Pentingnya mengkaji akar penyebab terjadinya fraud, pertama dikarenakan banyaknya kasus korupsi yang pada akhirnya menghambat jalannya roda pemerintahan, sehingga tujuan dari pembangunan itu sendiri, yaitu mensejahterahkan masyarakat tidak akan pernah tercapai.

Instansi pemerintah seperti Pemerintah Kota (BPPKAD), Dinas Pendapatan Daerah (BPPRD) dan Samsat merupakan instansi pemerintah yang memiliki peran sangat penting dalam roda pemerintahan, dalam penerimaan keuangan daerah, terkait dengan PAD dan penggunaan anggaran, khususnya dalam penelitian ini untuk daerah kota Banjarbaru, dalam mencegah terjadinya fraud berupa korupsi di sektor pemerintah.

Berdasarkan latar belakang yang telah dikemukakan, dapat dirumuskan inti permasalahan yang ingin dijawab dalam penelitian ini yaitu:

1. Apakah tekanan, peluang dan rasionalisasi berpengaruh secara simultan terhadap fraud di Sektor Pemerintahan Kota Banjarbaru?

2. Apakah tekanan, peluang dan rasionalisasi berpengaruh secara parsial terhadap fraud di Sektor Pemerintahan Kota Banjarbaru?

3. Diantara tekanan, peluang dan rasionalisasi mana yang berpengaruh paling dominan tehadap fraud di Sektor Pemerintahan Kota Banjarbaru?

\section{Kajian Literatur}

Pengertian dasar fraud menurut Garner (2004) adalah penyalahartian kebenaran atau penyembunyian fakta yang materiil yang menyebabkan seseorang bertindak merugikan terhadap pihak lain. Sedangkan menurut Alridge dan Parry (1985), fraud adalah tindakan yang tidak jujur dengan tujuan untuk menipu pihak lain untuk keuntungan pelaku yang merugikan pihak yang menjadi korban.

Berdasarkan dari beberapa definisi ini, dapat diartikan secara luas bahwa fraud terkait dengan penipuan (deception), ketidakjujuran (dishonest) dan niat (intent). Fraud menyangkut cara-cara yang dihasilkan oleh akal manusia yang dipilih oleh seseorang untuk mendapatkan suatu keuntungan dari pihak lain dengan penyajian yang salah/palsu. Kecurangan mencakup kejutan, tipu daya, cara-cara licik dan tidak jujur yang digunakan untuk menipu orang lain. Hal ini sejalan dengan pendapat Singleton et al (2006), yang mengemukakan bahwa fraud, theft, defalcation, irregularities, white collar crime, dan embezzlement adalah terminologi yang seringdipertukarkan.

Pengklasifikasian Penyebab Fraud. Menurut $\mathrm{O}^{e e}$ Gara (2004) fraud dapat dilihat dari 2 (dua) dimensi, yakni jenis fraud dan pelaku fraud. Jika dilihat dari jenisnya, maka fraud terdiri dari: penyalahgunaan internal atau korupsi, dan kecurangan dalam pelaporan. Association of Certified Fraud Examiners (ACFE), salah satu asosiasi di USA yang mempunyai kegiatan utama dalam pencegahan dan pemberantasan kecurangan, mengkategorikan kecurangan dalam tiga kelompok, yaitu : kecurangan laporan keuangan (financial statementfraud), penyalahgunaan aset (asset misappropriation), dan korupsi (corruption).

Kecurangan laporan keuangan (fraudulent statements atau financial statement fraud) dapat didefinisikan sebagai kecurangan yang dilakukan oleh manajemen dalam bentuk salah saji material laporan keuangan yang merugikan investor dan kreditor. Kecurangan ini dapat bersifat financial atau kecurangan non financial. Jenis fraud ini sangat dikenal para auditor yang melakukan general audit (opinion audit).

Penyalahgunaan aset (Asset Misappropriation) dapat digolongkan ke dalam kecurangan kas dan kecurangan atas persediaan dan aset lainnya, serta pengeluaran-pengeluaran biaya secara curang (fraudulent disbursement). Asset misappropriation atau "pengambilan" aset secara ilegal dalam bahasa sehari-hari disebut mencuri. Namun dalam istilah hukum," 
mengambil" aset secara ilegal (tidak sah atau melawan hukum) yang dilakukan oleh seseorang yang diberi wewenang untuk mengelola atau mengatasi aset tersebut, disebut menggelapkan.

Setiap orang dapat melakukan fraud. Kadang-kadang sulit dipercaya, seseorang yang kita pandang jujur, taat beragama, berpendidikan, dari lingkungan sosial yang dihormati, bahkan dari kalangan berada, ternyata terlibat dalam kasus fraud. Bagaimana hal ini bisa terjadi?, Dennis Greer menyebut tiga elemen kunci yang disebut sebagai segitiga fraud (fraud triangle) yang mendorong seseorang atau sekelompok orang

melakukan fraud yaitu: adanya tekanan, adanya kesempatan, dan adanya alasan pembenaran. Elemen pertama dan ketiga lebih melekat pada kondisi kehidupan dan sikap mental/moral pribadi seseorang, sedangkan elemen kedua terkait dengan sistem pengendalian internal dalam suatu organisasi atau perusahaan.

Pandangan lain dari sisi perilaku manusia, dijelaskan oleh Bologna et al (1987) berdasarkan GONETheory, yang terdiri dari 4 (empat) faktor yang mendorong seseorang berperilaku menyimpang dalam hal iniberperilaku fraud, yaitu: keserahkaan (greed), kesempatan (opportunity), kebutuhan (needs), dan pengungkapan (exposure). Keserakahan berkaitan dengan adanya perilaku serakah yang secara potensial ada di dalam diri setiap orang. Kesempatan berkaitan dengan keadaan organisasi atau instansi atau masyarakat yang sedemikian rupa sehingga terbuka kesempatan bagi seseorang untuk melakukan kecurangan terhadapnya. Kebutuhan berkaitan dengan faktor-faktor yang dibutuhkan oleh individuindividu untuk menunjang hidupnya yang menurutnya wajar; dan pengungkapan berkaitan dengan tindakan atau konsekuensi yang akan dihadapi oleh pelaku kecurangan apabila pelaku ditemukan melakukan kecurangan.

\section{Metode Penelitian}

Jenis penelitian yang digunakan dalam penelitian ini adalah penelitian komparatif, yaitu jenis penelitian yang digunakan untuk membandingkan dua kelompok atau lebih dari suatu variabel tertentu. Menurut Natsir (2005 : 58) penelitian kmparatif adalah sejenis penelitian yang ingin mencari jawaban secara mendasar tentang sebab- akibat, dengan menganalisis faktor-faktor penyebab terjadinya atau munculnya suatu fenomena tertentu.

Dalam pengambilan sampel tentunya perlu menggunakan beberapa metode. Metode yang digunakan dalam penelitian ini adalah purposive sampling dengan kriteria pegawai yang mempunyai pengaruh dalam melakukkan fraud, yaitu pemegang jabatan pengelola keuangan (pejabat pengadaan barang/jasa) diantaranya: Kuasa Pengguna Anggaran (KPA), Pejabat Pembuat Komitmen (PPK), Pejabat Pelaksana Teknis Kegiatan (PPTK), Bendahara Pengeluaran, dan Bendahara Pembantu Pengeluaran pada Pemko (BPPKAD), Dispenda (BPPRD) dan Samsat Kota Banjarbaru. Sampel yang diambil dalam penelitian ini berjumlah 42 orang (dengan total 65 responden).

Penelitian ini bertujuan ingin mengetahui pengaruh factor-faktor penyebab fraud yaitu variabel tekanan, peluang dan rasionalisasi terhadap fraud. Berdasarkan tujuan itu, digunakan analisis data. Analisis tersebut dapat digunakan untuk mencari hubungan dan membuktikan hipotesis hubungan dua variabel atau lebih. Untuk membuktikan 3 hipotesis pertama digunakan analisis regresi linier sederhana. Analisis ini digunakan untuk mencari hubungan antara variabel bebas (X) dengan variabel terikat (Y) secara simultan. Sedangkan untuk membuktikan hipotesis terakhir digunakan analisis linier berganda.

Analisis ini digunakan untuk mencari hubungan beberapa variabel bebas (X1,X2, X3) dengan variabel terikat (Y) secara parsial.. Dalam analisis regresi linear berganda menurut Wapole dan Myers (1986 : 336) beberapa variabel penjelas ( Variabel Independent ) digunakan 
untuk memprediksi nilai dari variabel dependen sehingga analisis regresi linear berganda yang digunakan dapat dirumuskan sebagai berikut :

$\mathrm{Y}=\mathrm{a}+\mathrm{b} 1 \mathrm{X} 1+\mathrm{b} 2 \mathrm{X} 2+\mathrm{b} 3 \mathrm{X} 3 \mathrm{e}$

Keterangan :

$\mathrm{Y}=$ Fraud $/$ Kecurangan

$\mathrm{X} 1=$ Pressure /Tekanan

$\mathrm{X} 2=$ Opportunity / Peluang

$\mathrm{X} 3=$ Rasionalization $/$ Rasionalisasi

a $\quad=$ Konstanta

b1, b2 = Parameter Model Regresi Linear Ganda dan Nilai Estimas dari data

e $\quad=$ Residual (Error)

\section{Hasil Penelitian dan Pembahasan}

Responden pada penelitian yang berjudul Analisis Faktor-faktor Penyebab Fraud di Sektor Pemerintahan Kota Banjarbaru berjumlah 42 responden. Gambaran umum responden dibagi berdasarkan usia, jenis kelamin, jabatan, lama bekerja, dan pendidikan. Deskriptif responden disajikan pada Tabel 1 .

Tabel 1. Deskripsi Responden

\begin{tabular}{lcc}
\hline \multicolumn{1}{c}{ Profil Responden } & Frekuensi & Presentase \\
\hline Usia: & & \\
\hline$<30$ Tahun & 16 & $38,1 \%$ \\
\hline 31- 40 Tahun & 17 & $40,5 \%$ \\
\hline 40 Tahun & 9 & $21,4 \%$ \\
\hline Total & 42 & $100 \%$ \\
\hline Jenis Kelamin: & & \\
\hline Perempuan & 29 & $69,0 \%$ \\
\hline Laki-laki & 13 & $31,0 \%$ \\
\hline Total & 42 & $100 \%$ \\
\hline Jabatan : & 9 & $21,4 \%$ \\
Pengelola Keu (KPA, PPK,PPTK) & 3 & $7,2 \%$ \\
Bendahara & 30 & $71,4 \%$ \\
Staf & 42 & $100 \%$ \\
Total & & \\
\hline
\end{tabular}

Dari hasil kuesioner yang sudah terkumpul ditabulasikan kemudian diolah menggunakan program SPSS 17.0. Langkah selanjutnya adalah uji validitas dan reliabilitas instrumen. hasil uji validitas terhadap semua item dalam penelitian ini bahwa semua item yang digunakan dari variabel tekanan, peluang, rasionalisasi dan fraud dinyatakan valid karena nilai rhitung lebih besar dari nilai rtabel. Hasil dari uji reliabilitas menunjukkan bahwa koefisien cronbach alpha terhadap butir yang valid pada variabel Tekanan sebesar 0.699, variabel Peluang sebesar 0.830, variabel Rasionalisasi sebesar 0,741 dan variabel Kecurangan (fraud) sebesar 0,801 yang masing-masing $>0.60$, ini menunjukkan bahwa instrumen yang digunakan dalam penelitian ini adalah reliable. 
Uji asumsi klasik yang dilakukan meliputi uji normalitas, linearitas, multikolinearitas, dan heteroskedastisitas. Hasil pengujian normalitas data dengan Uji One Sample KolmogorofSmirnov Test, menunjukkan nilai Asymp. Sig (2-tailed) sebesar 0,786 yang lebih besar dari 0,05 sehingga dapat disimpulkan bahwa semua variabel dalam penelitian ini terdistribusi secara normal. Hasil Uji Linieritas menunjukan bahwa nilai signifikansi dari masing-masing variabel lebih besar dari 0,05 yang artinya terdapat hubungan yang linier secara signifikansi antara variabel dependen dengan variabel independen. Hasil uji melalui Variance InflationFactor (VIF) Tekanan, Peluang, dan Rasionalisasi menghasilkan nilai tolerance $>0,1$ sedangkan nilai Variance InflationFactor(VIF) < 10. Dengan demikian dapat disimpulkan dalam model regresi ini tidak terjadi multikolinearitas antar variabel independen tersebut. Dari hasil uji Heterokedastisitas terlihat bahwa tekanan (pressure)memiliki nilai 0.099>0.05, peluang (opportunity) memiliki nilai 0.726>0.05 dan rasionalisasi (rasionalization) memiliki nilai0,146 $>0.05$, sehingga semua variabel bebas heteroskedastisitas.

Pengujian hipotesis dalam penelitian ini menggunakan analisis regresi berganda (multiple regression analysis). Pada penelitian ini hipotesis yang diajukan adalah tekanan (pressure), peluang (opportunity) dan rasionalisasi (rasinalization)yang mempengaruhi Kecurangan (fraud).Hasil hipotesis dapat dilihat pada Tabel 2

\section{Tabel 2. Hasil Analisis Regresi Linier Berganda}

\begin{tabular}{|c|c|c|c|c|c|c|c|}
\hline $\begin{array}{l}\text { Variabel } \\
\text { Dependen }\end{array}$ & $\begin{array}{c}\text { Variabel } \\
\text { Independen }\end{array}$ & $\begin{array}{c}\text { Koefisien } \\
\text { Regresi }\end{array}$ & $t_{\text {hitung }}$ & $\mathrm{r}_{\text {partial }}$ & $\mathrm{r}_{\text {partial }^{2}}$ & Sig & $\begin{array}{c}\text { Keterang } \\
\text { an }\end{array}$ \\
\hline \multirow[t]{3}{*}{ Fraud } & Tekanan & 0.255 & 2.100 & 0.275 & 0.075625 & 0.042 & Signifikan \\
\hline & Peluang & -0.295 & -2.350 & -0.307 & -0.094249 & 0.024 & Signifikan \\
\hline & Rasionalisasi & 0.513 & 2.789 & 0.365 & 0.13225 & 0.008 & Signifikan \\
\hline \multicolumn{2}{|c|}{ Konstanta } & $=8.491$ & & Fhitung & & $=6,817$ & \\
\hline \multicolumn{2}{|c|}{$t_{\text {tabel }}$} & $=2.02269$ & & Sig F & & $=0,001$ & \\
\hline \multicolumn{2}{|c|}{ Multiple R } & $=0,350$ & & $F_{\text {tabel }}$ & & $=2,61$ & \\
\hline \multicolumn{2}{|c|}{ Adjusted R square } & $=0,299$ & & $\mathrm{E}$ & & $=3,503$ & \\
\hline
\end{tabular}

Berdasarkan hasil perhitungan analisis regresi berganda pada Tabel 2 diatas maka diperoleh model persamaan regresi berganda sebagai berikut:

$\mathrm{Y}=8.491+0.255-0.295+0.513+\mathrm{e}$

Dari hasil uji regresi, maka dapat dilihat bahwa nilai stastistik F adalah 6.817 dengan nilai signifikan 0.001, hal ini menunjukkan bahwa tekanan, peluang dan rasionalisasi mempengaruhi kecurangan (fraud) sehingga pengujian hipotesis dapat dianalisis lebih lanjut. Tabel 4.9 juga memperlihatkan bahwa Koefisien determinasi R2 sebesar 0.350. Hal inimenunjukkan bahwa $35 \%$ kecurangan (fraud) dipengaruhi oleh tekanan, peluang dan rasionalisasi sedangkan sisanya sebesar $65 \%$ di pengaruhi oleh variabel lain yang tidak diteliti.Hasil diatas menunjukkan hipotesis pertama (H1) dapat diterima, dimana nilai Fhitung lebih besar daripada Ftabel yaitu $6.817>2.61$.

Hasil uji t dapat dilihat pada Tabel diatas. Hasil pengujian hipotesis kedua (H2) menunjukkan nilai thitung dari variabel tekanan sebesar 2.100, variabel peluang 2,350 dan variabel rasionalisasi 2.789 lebih besar dari nilai ttabel sebesar 2.022. Sehingga dapat disimpulkan bahwa tekanan, peluang dan rasionalisasi berpengaruh secara parsial terhadap kecurangan (fraud) sehingga hipotesis kedua diterima.

Uji dominan berdasarkan hasil pada Tabel 2 menunjukkan bahwa nilai rpartial $\neg 2$ dari masing-masing variabel independen yaitu tekanan (0.075625), peluang (-0.094249) dan 
rasionalisasi (0.13225) terhadap variabel dependen yaitu fraud pada Pemerintah Kota Banjarbaru. Berdasarkan hasil tersebut dapat disimpulkan bahwa variabel rasionalisasi (X3) merupakan variabel independen yang memberikan pengaruh terbesar yaitu sebesar 0.13225 terhadap fraud di Pemerintah Kota Banjarbaru.

\section{Kesimpulan}

Berdasarkan pada temuan-temuan pada penelitian ini, dapat disusun beberapa kesimpulan sebagai berikut:

1. Seluruh variabel berpengaruh secara bersama-sama (simultan) sedangkan secara parsial berpengaruh signifikan positif dari variabel X1 dan X3 sedangkan variabel X2 berpengaruh signifikan negative. Variabel yang paling dominan berpengaruh adalah variabel rasionalisasi yang ditunjukkan oleh hasil uji r partial ${ }^{2}$.

2. Tekanan berpengaruh secara signifikansi dan positif terhadap Kecurangan (fraud), menunjukkan semakin tinggi tekanan yang ada terhadap pegawai maka akan meningkatkan tindakan terhadap Kecurangan (fraud).

3. Peluang berpengaruh secara signifikansi terhadap Kecurangan (fraud). menunjukkan semakin tinggi peluang yang ada maka akan menurunkan tindakan terhadap Kecurangan (fraud).

4. Rasionalisasi berpengaruh secara signifikansi dan positif terhadap Kecurangan (fraud). menunjukkan semakin tinggi rasionalisasi yang ada terhadap pegawai maka akan meningkatkan tindakan terhadap Kecurangan (fraud).

berikut:

Saran yang bisa disampaikan menyikapi temuan-temuan dari penetlian ini adalah sebagai

1. Sebaiknya Pemerintah Kota Banjarbaru melakukan Evaluasi secara berkala terhadap sistem pengawasan dan pengendalian dan pelaksanaan good governance. Serta Memperbaiki perilaku yang diwujudkan dengan mengembangkan sikap komitmen terhadap negara, daerah dan masyarakat.

2. Peneliti selanjutnya agar memperbanyak sampel penelitian dan untuk hasil yang lebih baik, dan dapat menggunakan variabel lain yang dapat mempengaruhi kecurangan, selain itu perlu ditambahkan metode lain seperti metode interview untuk mendukung penjelasan hasil penelitian,

\section{DAFTAR PUSTAKA}

Albrecht, W. S., Chad O. Albrecht, 2002. Fraud Examination.Thomson-South Western.

Amin W.tunggal. 2003. Internal Auditing (suatupengantar), Jakarta: Harvarindo

Amrizal. 2004.Pencegahan dan Pendeteksian Kecurangan Oleh Internal Auditor.Jurnal Akuntansi. Jakarta

Arens, Alvin A. 2008. Auditing dan Jasa Assurance Pendekatan Terintegrasi JilidI. Erlangga. Jurnal akuntansi. Jakarta.

Association of Certified Fraud Examiners (ACFE), 2004.Report To The Nation On Occupational Fraud AndAbuse, TX: Association of Certified Fraud Examiners.

O'Gara, John D. 2004. Corporate Fraud: Case Studies Detection Prevention. The Institute of Internal Auditors

Singleton, T. W., Singleton, A. J., Bologna, G. J., Lindquist, R. J., 2006. Fraud Auditing and ForensicAccounting. John Wiley \& Sons, Inc., New Jersey. 
Tim Penyusun Modul Program Pendidikan Non Gelar Auditor SektorPublik, Sekolah Tinggi Akuntansi Negara. 2007.Pengantar AuditKecurangan.PenerbitSekolahTinggiAkuntansi Negara. Jakarta.

Tuanakotta,T. M., 2010. Akuntansi Forensik \& Audit Investigatif, Edisi 2, Penerbit Salemba Empat. Jakarta.

-----------, 1999.Undang-undang RI Nomor 31 Tahun 1999 Tentang Pemberantasan Tindak Pidana Korupsi. Jakarta.

-----------, 2001.Undang-undang RI Nomor 20 Tahun 2001 Tentang Perubahan Atas UndangUndang Nomor 31 Tahun 1999 Tentang Pemberantasan Tindak Pidana Korupsi. Jakarta.

-----------, 2002.Undang-Undang RI Nomor 30 Tahun 2002 Tentang Komisi Pemberantasan Tindak Pidana Korupsi. Jakarta

Tunggal. Amin Wijaya.2010.Dasar-dasar audit internpedomanuntuk auditorbaru. Jakarta: Harvarindo.

Wilopo. 2006. Analisis Faktor-faktr yang Berpengeruh terhadap KecenderunganKecurangan Akuntansi: Studi pada Perusahaann Publik dan Badan Usaha Milik Negara di Indonesia". Simposium Nasional Akuntansi (SNA 9) Padang.

Yuwono, Ino dkk. 2005. Psikologi Industri dan Organisasi. Jurnal. Surabaya:

akultas Psikologi Universitas Airlangga 